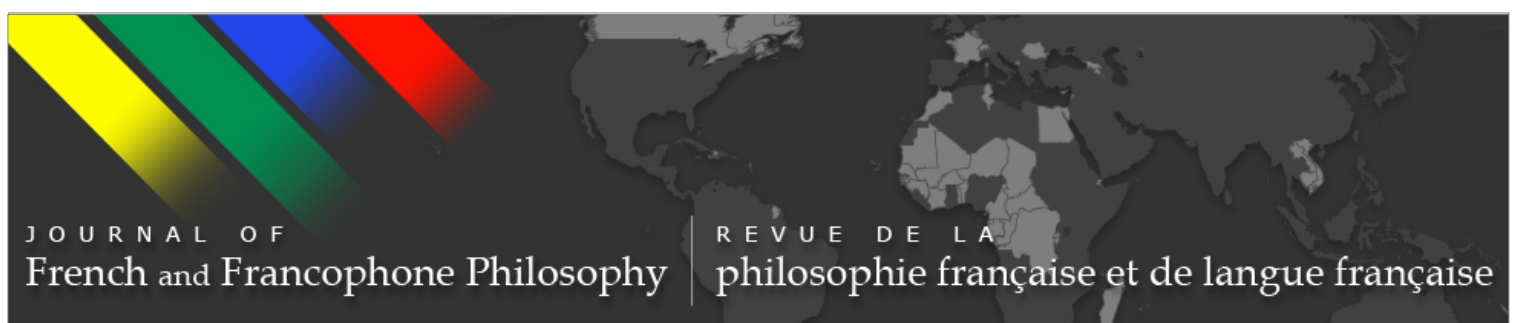

\title{
The Persistence of Utopia
}

Plasticity and Difference from Roland Barthes to Catherine Malabou

\author{
Jennifer A. Wagner-Lawlor
}

Journal of French and Francophone Philosophy - Revue de la philosophie française et de langue française, Vol XXV, No 2 (2017) pp 67-86.

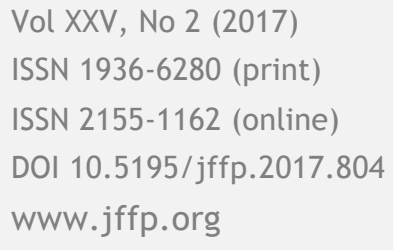

\section{(oc) EY-NG-ND}

This work is licensed under a Creative Commons Attribution-Noncommercial-No Derivative Works 3.0 United States License.

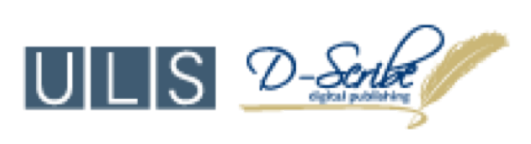

This journal is operated by the University Library System of the University of Pittsburgh as part of its D-Scribe Digital Publishing Program, and is co-sponsored by the University of Pittsburgh Press 


\title{
The Persistence of Utopia
}

\section{Plasticity and Difference from Roland Barthes to}

\section{Catherine Malabou}

\author{
Jennifer A. Wagner-Lawlor \\ Pennsylvania State University \\ "Utopias are designed to keep people out."-Toni Morrison ${ }^{1}$
}

The theorizing of utopia is a persistent theme throughout several generations of the French continental tradition and, alongside the process theory of Alfred North Whitehead, to a large degree recuperates the concept of utopia from its supposed dismissal by Marx and his intellectual descendants. Most recently, attention to the notion of plasticity, popularized (relatively speaking) by Catherine Malabou, extends speculation on utopian possibility. Compelled to answer to Marx's denigration of utopia as fantasy, the tendency was (still is, for many) to compensate for the absence of a programmatic politics by stressing what is "useful" about utopian dreaming, and therefore where or how exactly a utopian text reveals or creates political drive, or motivates political action. This is what gets called utopian anticipation, and we can look back at the history of utopian writing, and note the precision of a writer's perception of tendencies in the present that are extrapolated as future possibilities. The "use" of utopia is fundamentally diagnostic from this point of view, as much as it is speculative.

Indeed, it is the speculative part, the non-concrete-ness of utopia, which provokes the skepticism of political and social philosophy. On the other hand, French theorists throughout the twentieth century generally approach utopian speculation not simply as a form of political modelling, but rather as a representation of imagining difference. A political concept of utopia traditionally seeks achievement of something that can be called "concrete"; indeed, the term concrete utopia commonly appears in Utopian Studies. From a purely literary standpoint, however, any given utopian narrative is as concrete as it can be or in fact needs to be. Contemporary

Journal of French and Francophone Philosophy | Revue de la philosophie française et de langue française Vol XXV, No 2 (2017) | www.jffp.org | DOI 10.5195/jffp.2017.804 
utopia theorists now tend to argue that "concretization" of any one utopian model is an outcome to be avoided. The so-called blueprint model is rejected as exclusionary and often reactionary-as Toni Morrison's epigraph suggests. What takes the place of the "blueprint" is a model of utopia far more plastic than concrete: indeed, I will argue that utopia is plastic, in the very sense that Malabou offers us today.

In this essay, I offer a theoretical grounding for thinking about utopia in terms of plasticity. Coming from two directions, I consider briefly the associations of the concept of utopia and the material plastic throughout the twentieth century. This account begins in 1953, when French philosopher Roland Barthes charges his compatriots to explicate cultural myths that harden into unchallenged habits of thought; this intellectual work is the only way of fighting (façon de militer) offered to them. Four years later arrives Mythologies, a full-throated attack on the "repetitive, fixed discourse" ${ }^{2}$ of politics, and an incisive critique of the "plasticization" of nature, of minds, of ideas and creativity. In an easily overlooked, three-page essay included in Mythologies collection, "Plastic" seems to celebrate a "miraculous" modern material fated to transform contemporary society in the Acceleration Age of Western capitalism. A closer reading reveals a dark warning against ideological conformity and a vision of a plasticized future incapable of creative evolution. Barthes would eventually (by 1975) speak of utopia explicitly in his work, as I shall discuss; and I will argue that his ultimately positive view of utopia, as opposed to myth, hinges precisely upon the notion of plasticity he represents so literally in the 1957 essay.

Fifty years on, philosopher Catherine Malabou publishes the groundbreaking What Should We Do With Our Brain?, a breakthrough in her own work on Hegelian plasticity and the beginning of a new materialist description of the structuring of life itself as an expression of plasticity. In so doing, Malabou offers a more optimistic_indeed vital(ist)_view for a utopian future: not the consumer utopia brought about through the "modern miracle" of plastic, but through the persistence of imaginal and vital forms of speculation made possible by neuroplasticity. Reading Barthes on plastic alongside Malabou on plasticity, what seems at stake for both writers is nothing short of life-affirmation, to borrow Nietzsche's term, through a necessary contestation of ideology. In "Plastic" Barthes can only visualize a world gradually plasticized into a kind of death-in-life, politically and aesthetically. Malabou's explorations into neuroscience and neuroplasticity propose a natural (sic) capacity for repair and resilience which the plasticity of all living cells makes possible; entropy gives way to renewed energy. Reproduction of sameness is disrupted by the production of difference.

I argue that theorists have overlooked the use of utopia as not only the reproduction of difference, or what Malabou calls positive plasticity, but also as, therefore, a disruption; Malabou might prefer the term accident here.

Journal of French and Francophone Philosophy | Revue de la philosophie française et de langue française

Vol XXV, No 2 (2017) | http://www.jffp.org | DOI 10.5195/jffp.2017.804 
Tracing the concept of plasticity from Barthes to Malabou, with a nod at Miguel Abensour, this essay teases out the links between a contemporary notion of plasticity to argue, simply put, that utopia is plastic. This plasticity of the concept ensures its political force. These links, obscured in "Plastic," Barthes makes only later in his writing. But for Malabou, plasticity underlies a principle of futurity and/as generativity, such that new forms, new meanings, new concepts emerge through difference. Utopia's horizons of potentiality depend on difference, and on non-achievement. Finally, I argue that the "persistence of utopia" (Abensour) as a form of thinking is the most important, and political, effect of utopian plasticity.

\section{A New Generation: The Utopian Myth of Plastic}

In the mid-1950s, cultural philosopher Roland Barthes is inspired to write the essay "Plastic" after attending an exhibition in Paris celebrating the virtue of this "miracle" material. The exhibit was a sort of World's Fair event, one of many launched from the 1930s to the 1950s in Europe and the United States. As Folke Kihlstedt notes, "these kinds of events in the postDepression United States "delivered to the large cross-section of American society ... a buoyant, optimistic message extolling the positive consequences of science and technology for life in the future." ${ }^{3}$ As several recent histories of plastic spell out, since the 1930s plastic has projected, as it were, a visionary landscape of economic and material plenty, as well as a future of open possibility for the modern consumer. ${ }^{4}$ In fact, the consumer is the target at the Paris exhibition, indeed at all such product fairs, as the cheap manufactured products plastic made available a consumer utopia such as the world had not seen. Historians agree, whether they are "pro" or "con" the dawning of the "Plasticene Age," that plastic made possible in a real sense the democratizing of modern consumerism.

Jeffrey Meikle, a historian of the plastics industry, adds that as long as plastics were seen as the cutting-edge industry for the future, plastics were extravagantly praised as the material "from which [Americans] would shape the precise contours of a desired future" that is "cleaner and brighter." The connection of plastic to a utopian future began even befpre World War II, when the new applications for plastic, as well as ongoing improvements in material science, suggested consumer-product possibilities that could fuel a new, post-war consumer market. Women's nylon stockings are introduced in 1939, and further celebrated at the 1940 World's Fair with the appearance, Venus-like, of "Miss Chemistry of the Future" from an oversized test tube. ${ }^{5}$ This was just the beginning of the plastic industry's incursion into fashion. According to Meikle, "journalists and advertisers built up so many utopian predictions about plastics in the postwar world" that by the 1950s "the older utopian vision of the white-coated laboratory chemist" combined with "the newer vision of a postwar plastic cornucopia" to configure the image of "molecule engineers" able to master the design of any kind of "new molecule" needed "for a given purpose." These engineers would

Journal of French and Francophone Philosophy | Revue de la philosophie française et de langue française 
"streamline" the United States and its Western allies smoothly into a modern age of unprecedented abundance. ${ }^{6}$ While the ubiquity of plastic products-to which Roland Barthes would respond-began to make them seem commonplace and "cheap," leading manufacturers redoubled marketing efforts to reclaim its reputation as the "modern miracle" by inventing a modern concept of "convenience." The return of women from war-time factory jobs to the home suggested strategic capture of the "women's market" with the seemingly irresistible triple-convenience promise of labor-saving, time-saving, and cost-savings. In a bizarre expression of plastic's labor-saving possibilities, DuPont promises that the "best things in life" come in Cellophane, and shows a baby being delivered by a stork in a sack of transparent plastic film (the very kind with labels warning of children and pets choking or suffocating).

In this general historical context of manufacturing ingenuity and stoked-up consumerism appears Barthes's essay. He investigates what he presciently recognizes as the visible form of the modern death drive: plastic. This claim might seem incommensurate with the brevity of the essay-just barely four pages-and with the celebratory, even triumphalist tone of the piece. To consider the relation of the essay to the title of the collection in which it appears, however, is to regard the colors of this rhetoric with a skeptical eye. Barthes' essay is simultaneously a celebration and a condemnation of this artificial material, invented a century earlier but suitable for widespread use as a consumer product material only after World War II. By the mid-1950s, the chemical and manufacturing industries, foreseeing unprecedented profits, promoted plastic as the modern material, and enlisted the genius of the bourgeoning advertising industry to tell the story of this remarkably versatile, durable, substance that promises to drive "history in the making."

This story, as much as the substance itself, is Barthes' subject: the myth, in short, of plastic. It is at once an origin myth, and a modern cultural myth. But like many robust myths, the symbolic story hides a barer reality. Obscured by the symbolic economy of a "plasticized world" of consumers, buoyed by modern notions of innovation and "convenience," Barthes sees a toxic underside: a world of "users" with an instrumentalist attitude toward other human beings, toward nature, toward life itself. "Plastic" narrates the myth of plastic as science fiction, presenting a possible world, not far off, as a kind of zombie-world. It is not just the aesthetics of plastic that Barthes rejects. While Barthes clearly does dislike things made of plastic-cheap, lifeless, fake copies of things once made with natural materials-at stake is something more abstract: the "conceptual matter" of plastic; that is, the plasticity of the individual and the social mind, in the post-war, modern age. Barthes makes it clear that plastic and plasticity are material figurings comprising a narrative regarding freedom and unfreedom in modern mass culture.

Journal of French and Francophone Philosophy | Revue de la philosophie française et de langue française

Vol XXV, No 2 (2017) | http://www.jffp.org | DOI 10.5195/jffp.2017.804 
Barthes clearly understands all this, and recognizes the genius behind plastic's mythical story. He recalls plastic's genealogical roots in imitation materials "historically bourgeois in origin," and locates plastic's value-or rather, its virtue (to which I will return), in its ability to fulfill the bourgeois desire for the appearances of wealth. Even this "pretention," however, is betrayed by a "fashion for plastic" that betrays the bare reality of its "decline" into a "household material." he says that like the common man, plastic is a material that "consents to be prosaic." ${ }^{8}$ With its artificial "fecund[ity]", 9 its easy availability, its infinite malleability, its "quick-change talent" for appearing in any desired color, texture, design, or shape, plastic stands as quite literally an unprecedented human achievement: the invention of a material developed for the sole purpose of its usability. A uniquely human material invention, its unique virtues of malleability and durability are betrayed by the utilitarian imperative placed upon it. Its very formlessness allows for infinite replication, for imitation of any other form. This essential use-value of plastic is born out of its paradoxical union of pliability and durability. In other words, plastic's very plasticity is its genius.

With a nod to the concept of plasticity as an aesthetic term, Barthes begins his essay by arguing that plastic is an "artificial Matter" that is also an idea. This idea has to do with the visibility of space. Opening the essay with the assertion that plastic is notionally "ubiquity made visible," ${ }^{10}$ he ends the essay with a seeming triumphant visionof a material take-over by, and even incorporation of, plastic:

[Nature] is no longer the Idea, the pure Substance to be regained or imitated: an artificial Matter, more bountiful than all the natural deposits, is about to replace her, and to determine the very invention of forms. ... The hierarchy of substances is abolished; a single one replaces them all: the whole world can be plasticized, and even life itself since, we are told, they are beginning to make plastic aortas. $^{11}$

There is more to this passage than the pros and cons of natural materials versus plastic. It is impossible not to hear echoes of once-conventional descriptions of art and aesthetics, "holding a mirror to Nature" as an artist's primary task. Barthes reiterates popular celebrations of this manmade substance out of which the natural world will be not simply imitated, but rivaled and replaced. Barthes suggests even more: plastic promises not simply to "mimic" nature, nor to "be" nature, but to be super-natural.

This is not the "plastic virtue" Malabou will refer to, in the sense of the plasticity "possessed by animals, plants, and living things in general."12 The "virtue" of plastic in Barthes' argument is its alleged capability of superseding those natural beings. In one respect, plastic represents a

Journal of French and Francophone Philosophy | Revue de la philosophie française et de langue française 
triumph of human ingenuity and inventiveness: it is a substance not found in nature anywhere: "More than a substance," Barthes writes, "plastic is the very idea of its infinite transformation. ... Plastic remains completely impregnated by this astonishment: it is less an object than the trace of a movement. And since this movement is here virtually infinite ... plastic is, ultimately, a spectacle to be deciphered: the spectacle of its end products." ${ }^{\prime 13}$ This is a moment of technological sublime, it seems; the "perpetual astonishment" before plastic is at the sight of the "proliferating forms of matter" that replicate endlessly. As the "trace" of the "very idea of its transformation," plastic stands as a unique material aporia, if such a thing can exist. Barthes' story is about production and reproduction, and the mythical and mystified belief that man can be more than simply "like a god" but himself God. The folly of such a fantasy motivates the plots of both ancient myth and, in our modern times, science fiction, starting with Mary Shelley's uncanny classic. That novel's ongoing hold on us has precisely to do with the Frankenstein's failure to adapt to a world that includes the monster he created. Western myth and science fiction alike share a brash positioning of man's fantasy at the brink of material reality, the line of a utopian horizon where the material and the immaterial merge: the dark edge of accelerationism.

The "thing-ness" of plastic products is, as we have seen, what concerns Barthes. From these products emerges a by-product of sorts: the myth itself, the narrative born (like Frankenstein's creature) of experiments in plasticity. The "story" of plastic and its endless proliferation of products is not just about the universal production and reproduction of consumer products for a world market. The story of plastic betrays itself as a peculiarly gendered account of (pro)creation without the need of Woman, given the right technology:

At the entrance to the stall, the public waits in a long line to see accomplished the magical operation par excellence: the conversion of substance. An ideally shaped machine, tabulated and oblong (the right shape to manifest the secret of an itinerary), effortless draws from a heap of greenish crystals a series of gleaming fluted pin trays. At one end the raw telluric substance, and at the other the perfect human object; and between these two extremes, nothing but a trajectory, scarcely watched over by a helmeted employee, half god, half robot. $^{14}$

This passage describes a technological birth scene, no less "miraculous" in its presentation than the Creature's birth in Frankenstein's lab. But Barthes' plastic birth parody involves scarcely any visible labor, the mother reduced to matrixial machine. Barthes' narrative of this reproductive process takes place without the exhausting intellectual and physical effort Shelley's legendary scientist puts in: the "indecent" violation of "nature's secrets"; the

Journal of French and Francophone Philosophy | Revue de la philosophie française et de langue française

Vol XXV, No 2 (2017) | http://www.jffp.org | DOI 10.5195/jffp.2017.804 
intentional supersizing, partly for "ease of assembly," partly for the sheer satisfaction of "bigger is better" for the "new race" of Man upon whom the scientist, as their creator, fantasizes.

The extrusion machine at the center of the scene that Barthes sketches out displaces, indeed makes entirely invisible, the "labor" of reproduction. In an almost primal scene, the machine is described in terms of a maternal body in labor: "[it is an] ideally shaped machine, tabulated and oblong (the right shape to manifest the secret of an itinerary)." ${ }^{15}$ This strange wording again aligns this technological birth narrative with Mary Shelley's earlier version. What is secret is the process by which an idea(l) is materialized; what is manifest are the products formed from that secret idea(l) and through that secret process. In Frankenstein the proprietary secret, as it were, is kept hidden for our own moral good. In "Plastic," we are not told why. Trade secrets. But the secrecy is for own good as well, for our own economic good, and for "goods" whose circulation is something like the lifeblood of a consumer economy.

The real labor, the "secret of the itinerary," is in revealing the plasticity of the myth; which is to say, the power of ideology. These are the proprietary secrets neither Dr. Frankenstein nor contemporary plastics manufacturers would reveal. The "ideal" shape of the machine itself represents or "manifests" the hidden secret. What makes the machine shape "ideal" is that it disguises, in the tropes of technology the labor of the mother's body. This machine's productive labor is easeful, quiet, and with a little oil labor can continue indefinitely. The value of maternal labor thus evacuated, the admiration of the observer no longer includes that agony, and the presentation of a unique "human object." We are to admire the smooth "effortless" operation of the labor involved in mechanical reproduction; and we are to admire the "very spectacle of the end products" (emphasis added).

The language of insemination and pregnancy, the echoes of maternity and labor (including midwifery) point toward the apparent generativity of the capitalist imagination. ${ }^{16}$ The scene performs the myth of plastic, with its gendering of technological reproduction and materiality. The maternal machine is feminine, yet built by man; the plastic is manmade, though it "bends just like a woman" (to borrow Bob Dylan's unfortunate lyric) and is the perfect material for the "proliferating forms" of capitalist desire. The spectacle lies not simply in the crowning of individual products themselves as they leave the machine - but the display of the variety and proliferation of plastic. Think of the display cases and shelving that make up the very architecture of the modern supermarket: the showcasing of plastic at this "exhibition" of plenty and consumer "choice" instantiates the ever-plastic ideological formations of desire and purchasing power.

Journal of French and Francophone Philosophy | Revue de la philosophie française et de langue française Vol XXV, No 2 (2017) | http://www.jffp.org | DOI 10.5195/jffp.2017.804 
Barthes does not mention that "raw" plastic, not yet molded, is called virgin plastic. The trope of sexual reproduction belies the superseding of embodied feminine creativity by the superior potency of masculine invention. The secret, the miracle, the manifestation, the ubiquity made visible: these are godly attributes belonging to "the mind" that "impregnates"; hence the "perpetual astonishment, the reverie of man [sic] at the sight of the proliferations of substance, detecting the connections (liaisons) between the singular of its origin and the plural of its effects" ${ }^{17}$ (emphasis added). The "singular of its origin" is not the machine, or the man, but an idea of selfgenerativity: the "plural of its effects" is the endlessly plastic display of objects symbolizing "the measure of man." Plastic does more than just replace nature, in other words. It stands for something, as a symbol, and stands in for something.

What plastic stands (in) for becomes clearer in another essay in Mythologies, entitled "Toys." In exploring the relationship of natural and artificial materials in children's toys, Barthes points more directly to the entangled relationship of material shaping with ideological shaping, production and reproduction. Barthes excavates the cultural myth underlying the production of children's toys in contemporary France with a critique not simply of "toy aesthetics" but also, relatedly in his view, of the deadening effects of that material takeover on children themselves:

The fact that French toys literally prefigure the universe of adult functions can only prepare the child to accept them all, constituting for him even before he can think about it the alibi of a Nature which has created for all time soldiers, postmen, and Vespas. ... [T] he child cannot constitute himself as anything but an owner, a user, never as a creator; he does not invent the world, he utilizes it[.] ${ }^{18}$

The plastic material from which these toys are molded informs what Barthes regards as the "posthumous life" of toy and child alike: the "elaborate" compounds "look both crude and hygienic, they eliminate the pleasure, the gentleness, the humanity of touch." ${ }^{19}$ Touch is the heart of aesthetics, its root-word referring not to the physical sense so much as the sensorium through we which are continuously touched, by each one of our senses, by objects around us, by other people. Barthes suggests, though he doesn't put it this way, that plastic is anaesthetic.

Because the essay "Plastic" follows "Toys" in the Mythologies volume, Barthes can develop the thought introduced in the passage above, to argue that plastic's negative predominance over nature eventually "will command the very invention of shapes." ${ }^{20}$ Plastic's designs are not just of us but on us: its very flexibility and acquiescence to form teaches passivity not action; acceptance, not resistance; compliance, not creativity. A plasticized world deterritorializes the "natural world" so-called, and is reterritorialized in the

Journal of French and Francophone Philosophy | Revue de la philosophie française et de langue française

Vol XXV, No 2 (2017) | http://www.jffp.org | DOI 10.5195/jffp.2017.804 
image of producer desire. Thus it represents the contemporary corruption of a familiar aesthetic ambition: the achievement through human inventiveness and technology of "a second nature" that perfects the first, and takes priority: "The hierarchy of substances is abolished; a single one replaces them all: the whole world can be plasticized, and even life itself since, we are told, they are beginning to make plastic aortas." 21

There it is: a generation of replicants whose fragile tissue and bones are replaced by durable and enduring plastic ones, molded to order in a single form: the consumer-and more specifically, a consumer whose desire to consume or "use" is molded by a bourgeois-capitalist political economy. Barthes ends his essay at the verge of a dystopian future, with the image of a plasticized heart. He wonders what a future of plasticized children in a plasticized world might be or become, or whether they are to become at all. The metaphorical nature of Barthes' investigation of a consumer utopia/dystopia and plasticity is made more concrete later, when his attitude toward utopia shifts from one of suspicion (as fantasy that displaces political action) to one of authorization:

What is a Utopia for? To make meaning. Confronting the present, my present, a Utopia is a second term which permits the sign to function: discourse about reality becomes possible, I emerge from the aphasia into which I am plunged by the panic of all that doesn't work within me, in this world which is mine. The Utopia is familiar to the writer, for the writer is a bestower of meaning. ${ }^{22}$

The "new semantics" characterizing his notion of text-as-utopia depends upon the disruption of meaning and "repetitive, fixed discourse" are possible only through an affirmative "break" with a reality that is (mis)shaped by cultural myths and formations.

\section{Plasticity, Progress, Reproduction}

While plasticity is not a concept that utopia theorist Miguel Abensour, contemporaneous to both Barthes (for a time) and Malabou, entertains his work represents an intermediate position between Barthes and Malabou. Utopia is a form of disruption, he suggests: "the non-coincidence between what was projected and what has come about throws us back into a new struggle for alterity." ${ }^{23}$ This foreshadows Malabou's stress on "the ontology of the accident," in her book of that title, ${ }^{24}$ and her call for a "new relationship with the image of our brain" — that is, with our potentially plastic identities. Abensour describes utopia not in terms of perfection or permanence, but persistence: “The persistence of utopia, we see, is due not so much to the repeated pursuit of a determinate content as to the everreborn movement toward something indeterminate." ${ }^{25}$ Finally, Absensour's interest in the "engine of enigmatic rebirth" echoes tropes of impregnation,

Journal of French and Francophone Philosophy | Revue de la philosophie française et de langue française 
birth, death and life that underlie Barthes's essay on plastic, and Malabou's later theorization of "the entre-deux," a conceptual time-space of neoHegelian intercourse between-two that makes something-else possible. The entre-deux corresponds to Abensour's notion of the repetitive encounter with alterity, which is the "essence of utopia ... [that] derives its force from nonaccomplishment."26

Catherine Malabou's work on plasticity clarifies the connection of utopia, futurity, and plasticity. She produces a series of studies concerning plasticity, grounded in her earliest work on Hegel. The Hypatia essay, "The Future of Hegel" (2000), is a précis for the English-speaking world of her 1996 monograph, L'Avenir de Hegel: Plasticité, Temporalité, Dialectique, which appeared in translation as The Future of Hegel: Plasticity, Temporality and Dialectic in 2005. What followed was the groundbreaking What Should We Do With Our Brain? (2004; English translation 2008), and the "sequel," Ontology of the Accident: An Essay on Destructive Plasticity (2009; English translation 2012). Malabou rarely speaks of plastic products per se with the exception of plastique; ${ }^{27}$ although in a 2013 essay, "The Living Room: Plasticity and Hospitality," ${ }^{28}$ she does point toward the "range of meanings" the words plasticity and plastic can embrace-including "all the various forms of "plastic' in our world [from the "plastic arts" to plastic wood, plastic money; plastic explosives]." In that essay as well she notes, as she had not in previous writing about plasticity, that she is anticipated at least to some degree by Roland Barthes's 1957 Mythologies text: "Roland Barthes alone has devoted to [plastic] a short chapter of Mythologies. ... Barthes warns ... that plastic's ability to become anything at all may reduce anything to nothing by dissolving all differences. ... Because plastic never presents itself without form, plastic is always thought as a factor of identification, standardisation, globalisation, and never as a possible welcome of the other."

This opening recognizes, however briefly, that both philosophers see in the unique materiality of plastic a radical paradox, whether one considers brain plasticity or material plasticity. With her grounding in Hegel and the dialectic, Malabou articulates a concept of plasticity that incorporates but extends beyond Barthes' investigation of the myth of plastic. But Barthes no less than Malabou apprehends a link between the idea of plasticity, creativity, hospitality, and a politics of freedom. The uncanniness of plastic Barthes describes and the "forms of contradiction" essential to Malabou's notion of plasticity are different approaches to the same crux: how to balance the twin powers of plasticity-resistance and yielding-against an entropy dictated by ideology, which by its nature wants to replicate itself endlessly.

It is not surprising, perhaps, that as tropes of gender difference emerge in their accounts. Barthes and Malabou tilt at a common enemy: latecapitalist universalism. Barthes' essay imagines the threat of negative

Journal of French and Francophone Philosophy | Revue de la philosophie française et de langue française

Vol XXV, No 2 (2017) | http://www.jffp.org | DOI 10.5195/jffp.2017.804 
plasticity's replication (reproduction of the same) rather than production, understood as producing the same-with-a-difference. Barthes perceives that the myth of plastic attempts to neutralize the toxicities of ideological conformity. Modernity's drive for "more and better" disguises a creative sclerosis, uncannily manifested in the proliferations, replications, and implications of a world that "can be plasticized" 29 and to a frightening extent, already has been. Malabou picks up where Barthes leaves off. Because the concept of plasticity also embraces the work of making meaning (in the process of taking form) and of resisting meaning (in the potentiality for deforming, reforming), the later philosopher theorizes being itselfLife-in terms of contemporary "plastic" virtues: that is, in terms creativity and resilience. Even as those terms are co-opted by our contemporary neoliberal political economy, ${ }^{30}$ as Barthes presciently foresees in "Plastic", Malabou can claim without irony, as Barthes does not, that plasticity is Life and extends the possibilities of utopia beyond the text.

Like Barthes, Malabou's thoughts turn to children. At stake for both are competing conceptions of the world as either deterministic and limited in possibility; or as "plastic," open to "possibilities for a becoming on the basis of the effacement of every future, for a transformation of the trace or mark, and for a historical transdifferentiation." ${ }^{31}$ Her example is the cohort of Romanian orphans left after the collapse of the Ceausescu regime in 1989. Her reading concerns an experiment around neuroplasticity-yet the political dimension is not obscure. So psychologically and physically deprived were these children, that physicians, psychologists and other scientists recognize a unique "case study" regarding the interaction of environment and the brain. The orphans' being-in-the-world under Ceausescu was, they learned, literally written on the body, their brain development actually in-formed by their abuse, expressed in physiological deformations that disrupted, in some cases arrested, mental and physical development.

What also scientists discovered, however, was that the children, removed from conditions of bare existence, regain neuronal plasticity. They are able to repair themselves and recover a mental pliability visible not only in behavior, but in the neuronal architecture of their brains. They could play, once again, with possibility: they were resilient, a quality Malabou contrasts with being flexible, or passive: "in order to return to themselves after the destructive trials they had suffered, these children had to create their own constancy [against] a reductionist discourse that models and naturalizes the neuronal process [... legitimating] a certain social and political functioning." 32 Malabou characterizes these "reconfigurations and this becoming" as constituted by "ruptures and resistance": "If these [children] were simply 'flexible'... they would be not resilient but conciliatory, that is to say, passive. But these individuals are, on the contrary, capable of changing difference." 33

Journal of French and Francophone Philosophy | Revue de la philosophie française et de langue française 
This suggests that the virtue of plasticity lies in the plurality of the origin, to reverse Barthes' formulation, not in its singularity; it is resistance to forces, not acquiescence to them, that strengthens every living thing. Resistance, Malabou implies, motivates adaptation, resilience, evolution itself. Therefore what we should do with our brains, Malabou argues, is what the brain wants: the capacity to resist, or de-form, hardened synaptic formations. Understanding the nature of brain plasticity as an active tension, an entre-deux ${ }^{34}$ or dialogue, Malabou pursues the vitality of human identity as an intra-agential process that regards the traditional body/mind relation in terms of entanglement, hardly a clear division, of matter and spirit. In fact, the singularity of the "stem cell" (a primary figure of plasticity for Malabou) lies in its capacity to "bring together the origin, as their name indicates, and the future, the capacity for self re-form." This capacity for selfreform stands therefore as "the best possible definition of plasticity ... this transformation or this transition-which cannot simply be the result of observation or of objective description." ${ }^{35}$

Where Barthes says that life can be plasticized, pointing ironically toward the death-in-life of such a development, Malabou argues that plasticity is life, whether one speaks of the life of the mind, the life of a body, or indeed the "life" of a text. Such a proposal directs her, as she well knows, toward the kind of new-materialist inquiry that has taken hold today. ${ }^{36}$ Recent commentators propose that even with his post-structuralist bearings, Barthes' attention to modes of affect may well anticipate the reintroduction of the body into contemporary criticism. Either way, both Barthes and Malabou clarify the urgency of understanding the concept of plasticity in all its paradoxes and complexities, and through its various registers (material; mental/psychological; political; aesthetical; ethical). Without doubt, the late-capitalist ideological and economic structures that currently dominate social, political, and economic movement resist strenuously any program for changing difference much less the possibility of radical reform(ing) of the world. As we know, the genius of capitalism is its capacity to neutralize any radical impulse, to incorporate it, to claim it for its own purposes. The recent popularity of nootropics and proprietary brain exercise regimes is fueled by the promise of a "brain upgrade" improving cognition, memory, creativity, and more. One frequently advertised product today gains its therapeutic power from a chemical derived from jellyfish. Putting aside the truth or not of therapeutic claims, it is interesting that the product's advertising stresses the sourcing from jellyfish: is there a more "plastic" animal form than the primitive jellyfish? Malabou comments on the specific interest in such animals:

In the course of evolution, regeneration-that possibility of naturally repairing all or part of the body-has largely been lost among mammals. This is why the discovery of stem cells-able to repair, reform, and regenerate organs

Journal of French and Francophone Philosophy | Revue de la philosophie française et de langue française Vol XXV, No 2 (2017) | http://www.jffp.org | DOI 10.5195/jffp.2017.804 
and damaged tissue-forces us to look two ways at once, both to the future and to the past: to the future, that is, towards the perfecting of technology destined for the medical use of these cells and to the past, to regeneration as very ancient property connected to primitive animals, such as hydra, planarians, and starfish. ${ }^{37}$

Barthes' Mythologies closes with essay entitled "Myth Today," which explains his impatience with "confusions" of Nature and History "in the description of our reality ... I wanted to expose in the decorative display of what-goes-without-saying the ideological abuse I believed was hidden there." Those "confusions," that abuse, are the workings of myth under late capitalism; and in a retrospective preface to a 1970 edition of Mythologies Barthes describes his work of thirteen years earlier an effort to "account in detail for [rather than "piously denounce"] the mystification which transforms petit bourgeois culture into a universal culture." ${ }^{38}$ As previously argued, Barthes' arch celebration of plastic production, from the "singular of the origin" to the "plural of the effects," unfolds a science-fiction narrative that foresees a cultural death-in-life, embodied as it were in the replication of "the same" through the proliferation of plastic consumer items-and human zombies. His call, in 1970, was for "cultural remediation" that would make possible a world that sees the virtue in generative reproduction as difference: "In actual fact, the knowledge contained in a mythical concept is confused, made of yielding, shapeless associations. One must fully stress this open character of the concept." ${ }^{39}$ Modern myths are alibis, notes Barthes, stories concealing their ideological content. ${ }^{40}$ To speak of plastic in terms of mythology - "the knowledge contained in a mythical concept" - is to look for unspoken aspects of that content. Ironically, however, the genius of capitalism is its ability to absorb challenges to its universalizing force: corporate greenwashing is an obvious example of a further obscuring in response to the clarity of a different story, based in alternative values than expansionism and profit.

Malabou's work on plasticity clarifies Barthes' suspicion of the aestheticization of plastic by the market as a political matter. This is the cause of the frisson plastic provokes in him, particularly in light of his closing line: that "all of Nature can be plasticized, and even Life itself." This (political) failure is the horror motivating Barthes' exposure of the bad faith in promoting plastic as a life-giving material, and in lending to this material a potentiality it does not own except though the market's attribution of "next generation" innovation. And as actual plastic forms are incapable of changing on their own, without a principle of (self-)generation of difference, plastic remains anamorphic stuff with the capacity to be molded, but not to repair itself. It has no material resiliency. With the integration of science that Barthes did not have, Malabou elucidates Barthes' ironical presentation of the "alchemical" (thus magical, mystical, mythical) essence of plastic/ity

Journal of French and Francophone Philosophy | Revue de la philosophie française et de langue française 
as the idea of transformation. Barthes' language of magic and myth metaphorizes what Malabou would make as literal as possible: the paradox of plasticity as at once informing and deforming, as well as reforming and transforming. ${ }^{41}$ Even more literally: Malabou's materialism describes plasticity "made flesh," the resiliency and reparability of the body, of the brain, of identity.

Malabou's proposition of "the new ontological transformability" 42 extends her description of a plasticity of/in difference fundamental to becoming rather than simply being (as a fixed shape or entity). This capacity returns us to plasticity, and to utopia. An intermediate, mobile positioning between positive and negative plasticity is necessary to remediate as well as transform. I propose that the concept of utopia comprises a Malabou's notion of a "positive plasticity," which preserves the resiliency allows for "a kind of contradictory constitution, a synthesis of memory and forgetting, of constitution and effacement of forms." 43 By re-presenting this capacity for reform, one avoids "producing a mirror image of the world," and produces "the form of another possible world." 44 This is the "agency of disobedience to every constituted form, a refusal to submit to a model." ${ }^{45}$

The resistant kernel of plasticity is the resistant agency of utopia, I propose. The previously favored model of utopia as blueprint, the so-called "static-state" model, exemplifies what Malabou calls negative plasticity: a yielding to, and subsequent hardening of, form. Such hardening is a refusal of difference, as (again) the epigraph from Toni Morrison signals. What our brain wants, what "we" want, and why utopia persists, is the capacity to change difference. ${ }^{46}$ If brain plasticity makes possible something like repair of the brain's regenerative capacity, and of the resilience of subjectivity, can we say the same of plasticized ideological formation beyond the mind? Malabou addresses cultural remediation quite specifically, throwing down "the plastic challenge" that subjectivity issues "between the upsurge and the explosion of form": "to do what they undoubtedly have never done: construct and entertain a relation with their brain as the image of a world to come." ${ }^{47}$ Malabou's argues that we are still foreign to the very historicity of the human brain. "Intimacy" with the work of our brains, she proposes, with the "consciousness of the brain," is something we used to be at home with-the ancient myths might be a perfect example here-but we no longer are. "In this sense, we are still foreign to ourselves, at the threshold of this 'new world,' which we fail to realize makes up our very intimacy itself." 48

Utopia is that "image of a world to come," born from a "utopian moment" of an encounter with alterity. In utopian narratives, the utopian traveler who stands "at the threshold of this "new world" quite precisely "finds himself" to be at once familiar and strange, the ontological basis of "who I am" being disrupted. One writer refers to this moment of confusion or wonder as the source of transformative energy: to turn away from that energy, that potentiality, is to be "dispossessed." As Malabou suggests, these

Journal of French and Francophone Philosophy | Revue de la philosophie française et de langue française

Vol XXV, No 2 (2017) | http://www.jffp.org | DOI 10.5195/jffp.2017.804 
encounters bring to us our most intimate experiences of "who we are." These are also moments when the stories we tell to ourselves and about ourselves-our myths-are illuminated: the attentive one, the resilient one, will look hard enough to understand the "open" (sometimes contradictory) shaping of myth itself, myth's plastic nature.

Perhaps a new way to think about utopia is by asking ourselves, as individuals and a network, or community, or nation: To what extent are we plastic? Barthes and Malabou, with Abensour between them, attune us to a notion of plasticity and/as difference, through their insistent and persistent attention to breaking of form even as form emerges. This essential plasticity, a co-constitution of agency and passivity, keeps vital an opening toward difference, and creates the capacity for the ongoingness of emergent formations. In this way only can we regard utopia as "sustainable" or "persistent": in its play of potentialities and possibilities, rather than replicant patterning. Utopia is the space that stays open to the possibility of new, emergent forms. It is positively plastic, aligning with Malabou's description (in What Should We Do with Our Brain?) of plasticity's contradictory nature, at which "possibility, the wholly other version," is held open by "the expectation of the arrival of another way of being," or, "a possibility of waiting." 49

\section{Conclusion: Utopian Biopolitics}

Malabou's most recent work extends these investigations of plasticity to an even more radical position: that the vital plasticity of life makes it necessary to think beyond the biopolitical, defined as "the means by which life is introduced 'into political techniques." ${ }^{50}$ This recent claim I see as the most incisive response to "the plastic challenge" she floats in What Should We Do with Our Brain?, and indeed in "One Life Only: Biological Resistance, Political Resistance," 51 Malabou takes to task "the political becoming of biological concepts" in contemporary thought, because "[p]aradoxically, they [Foucault and Agamben] expel the biological that is supposed to constitute their core--and it thereby becomes their unthinkable residue." ${ }^{2}$ Arguing for "a new materialism asserting the coincidence of the symbolic and the biological" Malabou can pick up where Barthes left off in Mythologies. She might say, that Barthes recognition' of plastic in biopolitical terms is limited by his emphasis on symbolic nature of plastic in the world, thereby pushing aside the vitality of the biological. Barthes can brilliantly describe the symbolic, biopolitical register of plasticity as "the idea of transformation," while asserting skepticism about the "virtues" of plastics with references to its "alchemical" and "miraculous" properties. But without a method of resisting the "mold of power," Barthes boxes himself in. $^{53}$

Malabou's intervention in the philosophy of biopower points directly at the privileging of the symbolic over the biological in the contemporary

Journal of French and Francophone Philosophy | Revue de la philosophie française et de langue française 
uptake of Foucault's term. Foucault himself, she argues, set philosophy on that path, ignoring "the reserve of possibilities inscribed in the living being itself." ${ }^{54}$ The consequence of this oversight (by philosophers and biologists) is profound, because it is insufficient "to defin[ing] the space of a theoretical disobedience against accusations of complicity among the science of the living being, capitalism, and the technological manipulation of life." ${ }^{25}$ Turning from the symbolic toward "life itself" offers that possibility, she argues:

What is most material and most vital in bodies must be thought as an interactive space, a formative and transformative dynamic of organic identity that operates within the economy of the living being itself, not outside of it. The gap that is opened between the living being and itself though the double interface of regimes of transmission and regimes of reproduction is a paradoxical memory gap in that it reveals the now fundamental shifting between the irreversibility and reversibility of difference. $^{56}$

The gap, this interactive space that maintains 'the living being as an open structure," is where difference not only "plays," but entertains and performs itself. This space is thus critical and creative, "plastic" precisely in its capacity to entertain the tension between negative and positive plasticity. This third space is where we can "entertain" the possibility of "a conception of the self as a source of reproduction," that might counter Barthes' vision of a plasticized future populated by ideological replicants. Indeed, the dialogue between Barthes and Malabou focuses on the importance of generativity; in Barthes it was figured as an ART-formed "pregnancy;" in Malabou, generativity goes beyond figuration and technique. Rather, biological generativity is investigated in terms of an essential, positive (thus characteristically open) plasticity. ${ }^{57}$

As if in response to Barthes, then, Malabou pushes toward a reconceptualizing of the self "as a source of reproduction," offering biologic potentialities that interact with conceptual (symbolic) potentialities in both directions. This interaction, she argues, is the source of our vitality. Barthes' tropes of pregnancy, production and reproduction are advanced and transformed in Malabou's emphasis on generativity and vitality-both material and immaterial-and on the capacity of the brain and body to repair itself. These characteristics of plasticity allow Malabou to argue without irony that plasticity is life, as noted earlier, in contradistinction to Barthes' understanding of plastic as the realization of the modern death drive. Barthes, however, did come to understand the plasticity of utopia in characteristically writerly terms: the plasticity of utopia for him lies in the possibility of a "new semantics."

Journal of French and Francophone Philosophy | Revue de la philosophie française et de langue française Vol XXV, No 2 (2017) | http://www.jffp.org | DOI 10.5195/jffp.2017.804 
Utopia is a (non-)site of deferral and of difference, as the common etymology of both words indicates [differe: carry across, scatter, disperse]. As a non-site, it is virtual, imaginary. ${ }^{58}$ The "real" state of utopia is a form of virtual reality, in the several senses of the word virtual. The plastic nature of Utopia makes possible the shaping, the realizing of what was not "known" in any objective sense, but that was already there as a potentiality, Barthes' "new semantics"; Malabou's "new relation to the image of our brain." In this way, both hold the "possibility of waiting" as an achievement in itself: the waiting enacts the process of imagining possibility, the shaping of thoughts we do not know we have, new ways of expressing them, different framings and representations, which take shape as we think and expect other-wise. We learn to speak again, to speculate, to regenerate: we persist.

1 See Morrison's 1998 interview with Elizabeth Farnsworth on PBS (Public Broadcasting System), http://www.pbs.org/newshour/bb/entertainment-janjune98-morrison_3-9/.

${ }^{2}$ See Christie V. McDonald's excellent The Dialogue of Writing: Essays in Eighteenth Century French Literature (Waterloo, Ontario: Wilfred Laurier University Press, 1984).

3 “Utopia Realized: The World's Fairs of the 1930s." 97-118 in Imagining Tomorrow: History, Technology, and the American Future, ed. Joseph J. Corn (Cambridge, MA: The MIT Press, 1986).

${ }^{4}$ The most important of these include: Stephen Fenichell's Plastic: The Making of a Synthetic Century (Harper-Collins, 1996); Jeffrey Meikle's American Plastic: A Cultural History (Rutgers UP, 1997); and Susan Freinkel's Plastic: A Toxic Love Story (Houghton Mifflin Harcourt, 2011). See also Heather Davis, "Life \& Death in the Anthropocene: A Short History of Plastic," 347-358 in Art in the Anthropocene: Encounters Among Aesthetics, Politics, Environments and Epistemologies, eds. Heather Davis and Etienne Turpin (Open Humanities Press, 2015).

${ }^{5}$ Philip Ball, "The Myth and Magic of Plastic," Nature Materials 3 (2004), 757.

${ }^{6}$ Meikle, "Plastic, Material of a Thousand Uses," 76-96 in Imagining Tomorrow, 79, 91-92. "Plastics and streamlining thus went together like hand and glove. One journalist even claimed that the requirements of molding technology had inspired streamlining as a design style. Such a statement was farfetched, but there can be little doubt that, as the 1930s came to a close, the 'miracle materials' were all the more closely linked ... to the concept of an approaching technological utopia" (88). 
7

Roland Barthes, Mythologies, trans. Richard Howard and Annette Lavers (New York: Hill and Wang), 194-195.

8 Barthes, Mythologies, 195.

9 Barthes, Mythologies, 195.

10 Barthes, Mythologies, 193.

11 Barthes, Mythologies, 195.

${ }^{12}$ Catherine Malabou, The Future of Hegel: Plasticity, Temporality and Dialectic. (New York: Routledge, 2005), 204.

13 Barthes, Mythologies, 193.

${ }^{14}$ Barthes, Mythologies, 193.

15 Barthes, Mythologies, 193.

16 http://criticallegalthinking.com/2013/05/14/accelerate-manifesto-for-anaccelerationist-politics/

17 Barthes, Mythologies, 194.

18 Barthes, Mythologies, 60.

19 Barthes, Mythologies, 60.

20 Barthes, Mythologies, 195.

21 Barthes, Mythologies, 195.

22 Roland Barthes by Roland Barthes [1975], trans. Richard Howard [Berkeley: University of California Press, 1977]), 76-77.

23 Miguel Abensour, “Persistent Utopia,” Constellations 15.3 (2008): 407.

24 Catherine Malabou, The Ontology of the Accident: An Essay on Destructive Plasticity (Cambridge, UK: Polity Press, 2012).

25 Abensour, “Persistent Utopia," 407.

26 Abensour, "Persistent Utopia," 409.

27 Catherine Malabou, “The Future of Hegel: Plasticity, Temporality, Dialectic," Hypatia 15 (2000): 196-220.

28 Accessed at http://www.springerin.at/dyn/heft_text.php?textid=2732\&lang=en , July 27, 2015. No pagination.

29 Barthes, Mythologies, 195.

30 Progress means innovation, a market-based notion of creativity, the "next generation" of the same; while resiliency these days refers to the capacity of socalled vulnerable communities to "become resilient," usually with the assistance of Western aid-a sort of developmental "bringing up to code" that slides over structural social and economic inequalities to which the West historically and

Journal of French and Francophone Philosophy | Revue de la philosophie française et de langue française Vol XXV, No 2 (2017) | http://www.jffp.org | DOI 10.5195/jffp.2017.804 
contemporaneously contributes. Thank you to David Bell for highlighting this connection in an earlier draft.

31 Malabou, What Should We Do With Our Brain? (New York: Fordham University Press, 2008), 76.

${ }^{32}$ Malabou, Our Brain, 68.

33 Malabou, Our Brain, 76-77; emphasis added.

${ }^{34}$ Malabou, Our Brain, 82.

35 Malabou, Our Brain, 80.

${ }^{36}$ See especially the work of Karen Barad, Meeting the Universe Half-Way: Quantum Physics and the Entanglement of Matter and Meaning (Durham: Duke University Press, 2007) and Jane Bennett, Vibrant Matter: A Political Ecology of Things (Durham: Duke University Press, 2010). Also see two major collections of newmaterialist theory: Material Feminisms, eds. Stacy Alaimo and Susan Hekman (Bloomington: Indiana University Press, 2008); and New Materialisms: Ontology, Agency, and Politics, edited by Diana Coole and Samantha Frost (Durham: Duke University Press, 2010).

37 “One Life Only: Biological Resistance, Political Resistance," Critical Inquiry 42 (Spring 2016): 438. The "brain upgrade" (https://blog.bulletproof.com/upgradeyour-brain/) exercise regimes also stress plasticity. An online advertisement from "Brain HQ" translates the scientific terminology for the layperson: "Brain plasticity-also called neuroplasticity-is an odd term for most people, with the word 'plastic' causing images of Tupperware or Saran Wrap to pop into your head. However, brain plasticity is a common term used by neuroscientists, referring to the brain's ability to change at any age - for better or worse. As you would imagine, this flexibility plays an incredibly important role in our brain development (or decline) and in shaping our distinct personalities. The science of neuroplasticity and the brain is the basis of our clinically proven brain training exercises" (http://www.brainhq.com/brain-resources/brain-plasticity/what-is-brainplasticity).

38 Barthes, Mythologies, ix.

${ }^{39}$ Barthes, Mythologies, 229, emphasis added.

${ }^{40}$ Barthes, Mythologies, 233.

${ }^{41}$ Consider in this context "worlding" as a "possibility in waiting" (87), a suspension of closure (Daniel Trend, Worlding: Identity, Media, and Imagination in a Digital Age [Boulder: Paradigm Publishers, 2013).

${ }^{42}$ Malabou, Changing Difference, 38-39.

Journal of French and Francophone Philosophy | Revue de la philosophie française et de langue française Vol XXV, No 2 (2017) | http://www.jffp.org | DOI 10.5195/jffp.2017.804 
${ }^{43}$ Malabou, Our Brain, 77.

${ }^{44}$ Malabou, Our Brain, 80.

${ }^{45}$ Malabou, Our Brain, 6.

46 From Malabou's Changing Difference, trans. Carolyn Shread (New York: Polity Press, 2011).

${ }^{47}$ Malabou, Our Brain, 82; emphasis added.

${ }^{48}$ Malabou, Our Brain, 2-3.

${ }^{49}$ Malabou, What Should We Do with Our Brain?, 87.

${ }^{50}$ Malabou, “One Life Only: Biological Resistance, Political Resistance," 430.

51 This critique is developed during European Graduate School course, "An Introduction to Biopolitics and Biopower" (2012), the lectures of which are available on YouTube. "One Life Only: Biological Resistance, Political Resistance” (2016, cited above), concisely summarizes her argument.

${ }^{52}$ Malabou, “One Life Only: Biological Resistance, Political Resistance," 431.

53 Malabou, “One Life Only: Biological Resistance, Political Resistance," 430.

${ }^{54}$ Malabou, “One Life Only: Biological Resistance, Political Resistance," 431.

${ }^{55}$ Malabou, “One Life Only: Biological Resistance, Political Resistance,” 433.

56 Ibid.

57 The essential plasticity of life grounds Malabou's recent critique of contemporary philosophical allegiances to what she sees as a deficient definition of biopower.

58 See Claire Colebrook, "On Not Becoming Man: The Materialist Politics of Unactualized Potential," in Material Feminisms, eds. Stacy Alaimo and Susan Hekman (Bloomington: Indiana UP, 2008): 52-84.

Journal of French and Francophone Philosophy | Revue de la philosophie française et de langue française Vol XXV, No 2 (2017) | http://www.jffp.org | DOI 10.5195/jffp.2017.804 